\title{
2-D Electrical Resistivity Tomography for Groundwater Potential in Basement Terrain of a Part of Ilorin Sheet 223 NW Nigeria
}

\author{
S. A. Aromoye ${ }^{1}$, S. A. Alimi ${ }^{1}$, O. S. Bello ${ }^{1}$, W. O. Raji ${ }^{2}$, L. O. Olawale ${ }^{3}$, D. S. Bonde ${ }^{4 *}$ \\ ${ }^{1}$ Department of Geology and Mineral Sciences, University of Ilorin, Ilorin, Nigeria \\ ${ }^{2}$ Departments of Applied Geophysics, University of Ilorin, Ilorin, Nigeria \\ ${ }^{3}$ Department of Geological Sciences, Osun State University, Osogbo, Nigeria \\ ${ }^{4}$ Department of Physics, Kebbi State University of Science and Technology, Aliero, Kebbi State, Nigeria
}

DOI:10.36348/SJET.2019.v04i09.004

| Received: 05.09.2019 | Accepted: 13.09.2019 | Published: 20.09.2019

*Corresponding author: Bonde Danladi Senchi

\section{Abstract}

In aiming to provide an economical supply of potable water for the inhabitant of University of Ilorin and its environs, 2D Electrical Resistivity Tomographic development was adopted. A 2-D Electrical Resistivity Tomographic Techniques involves the application of gridded Wenner electrode arrangement in determining the variation of subsurface resistivity distribution. The surveying were carried out on field by employing 7 profiles containing 22 layouts all together with a constant surveying lengths of $150 \mathrm{~m}$. The data obtained on field were inverted to obtain a pseudo-section where clearer models of the depth and apparent formation resistivity can be viewed at the same time using EarthImager Software. Three geo-electric layers were delineated which are Top soil, weathered/fractured Basement and fresh Basement. Out of the 7 profiles obtained the fresh Basement rock was only seen at profile F-F' having resistivity values ranging from 2000.1 to $10000 \Omega \mathrm{m}$. The thickness of the weathered/fractured basement (aquifer) is generally greater than $22.0 \mathrm{~m}$ and with a low resistivity values which are less than $30 \Omega \mathrm{m}$ at some zones. In conclusion, this study shows some levels of confidence that the groundwater potential within Unilorin substratum is of economic volume that is capable to sustain Unilorin and its environs.

Keywords: 2-D Electrical Resistivity Tomography, inversion, fresh Basement, Weathered/Fractured Basement, Regolith, Substratum.

Copyright @ 2019: This is an open-access article distributed under the terms of the Creative Commons Attribution license which permits unrestricted use, distribution, and reproduction in any medium for non-commercial use (NonCommercial, or CC-BY-NC) provided the original author and source are credited.

\section{INTRODUCTION}

Water is as important as any other classes of food in human's life. Groundwater as a source of water required an adequate exploration techniques to pinpoint layers where an economical volume of potable water could be exploit. Groundwater in Basement Complex terrain might be a bit difficult due to the low porosity and permeability nature of the rocks, previously it was assumed to be poor aquifers or with limited groundwater yield [1]. Thus, groundwater in a Basement Complex terrain is tending towards zero or minimal because this is only confined to fractured, weathered/regolith zones within this rock. In Basement Complex terrain, groundwater potential depends on the thickness of the weathered/fractured layer [2]. The overburden has high porosity and contains some quantities of water but with low permeability due to high clay content [3]. The fractured basements rocks are the primary source to store and permit the movement of groundwater [4]. Groundwater exploration and development should be targeted towards the fractured basement in Basement terrain areas with relatively thick overburden overlies fractured zones $[5,6]$.

The Electrical Resistivity Tomography (ERT) method is an electrical testing method where current is induced into the subsurface through two current electrodes and the electrical potential difference between two potential electrodes were measured accordingly. There are different electrode arrays which could be used for this process, but all arrays are aimed at gathering data to estimate lateral and vertical variations in subsurface resistivity values. ERT can be used to delineate variations in the subsurface geology which could be lithology, presence of groundwater, fractured zones, presence of contamination plume, and variations in soil saturation. ERT is often the best option for mapping cavities such as caves, limestone/karst and evaporate dissolution sinkholes. Electrical methods are mostly affected by geochemistry of the subsurface that is, the grain size distribution, groundwater chemistry and or presence of 
contamination plume. A 2-D Electrical Resistivity Tomography method is a proven technique to investigate shallow subsurface structures in various environments [7-9]. Previous studies have shown that 2D ERT have been used in bedrock detection, geological mapping and groundwater investigation $[10,11]$.

The present study employed an application of electrical resistivity methods to identify the potential of the subsurface geological structures favourable for groundwater potentials in University of Ilorin and its environs. A 2-D Electrical Resistivity Tomographic method was used due to its high signal to noise strength and Wenner electrode configuration was employed to depict a 2-D model of the subsurface geo-electric sections. An electrical resistivity tomography provides more detailed models of the subsurface by depicting both the horizontal and vertical resistivity variations in the survey line even in the presence of geological complexities [12]. This study is very important because of a vast increment in the population of the University community and the proposed Agricultural project that will surely involves large consumption of potable water in the area.

\section{Location and Geological Settings}

The study area is the present University of Ilorin, main campus which is located within latitude $8^{\circ} 27^{\prime} 00^{\prime \prime} \mathrm{N}$ and $8^{\circ} 30^{\prime} 00^{\prime \prime} \mathrm{N}$ and longitudes $4^{\circ} 38^{\prime} 00^{\prime \prime}$ $\mathrm{E}$ and $4^{\circ} 45^{\prime} 00^{\prime \prime} \mathrm{E}$ on a scale of 1:50000 (Fig-2). It covers a total area of about $75.264 \mathrm{~km}^{2}$. Some neighbouring settlements around University of Ilorin include Olokobiri, Aiyereke-Ile, Atere, Agunbiade, Bada, Alaya, Isokun, Agbada, Jibowu, FolawiyoFolatere, Jalala Agogo, Bolorundoro, Tanke Oke-Odo. The study area is situated in a transition zone between the forest and savannah region of Nigeria. University of Ilorin campus is situated within the Precambrian Basement Complex of Southwestern Nigeria (Fig-1). Its Basement Complex comprises of Crystalline Basement rocks of high grade metamorphic rock facies. The Crystalline Basement rocks in Kwara State must have been affected by both Eburnean and Pan-African Orogeny. The magmatization and metamorphism of the ancient Metasediment was caused by Eburnean Orogeny while the intrusion of the Granitic materials was produced by Pan-African Orogeny [13]. The Geological Map of the Northeastern portion of Ilorin Sheet $223 \mathrm{NW}$ (Fig-2) and the mapped rocks were Migmatite-Gneiss Complex, Banded gneiss, Porphyroblastic Gneiss, Augen Gneiss, Granite Gneiss, Quartzite, Older Granite rocks (Granite), and Late intrusive rocks (Pegmatitic intrusions, Quartz veins).

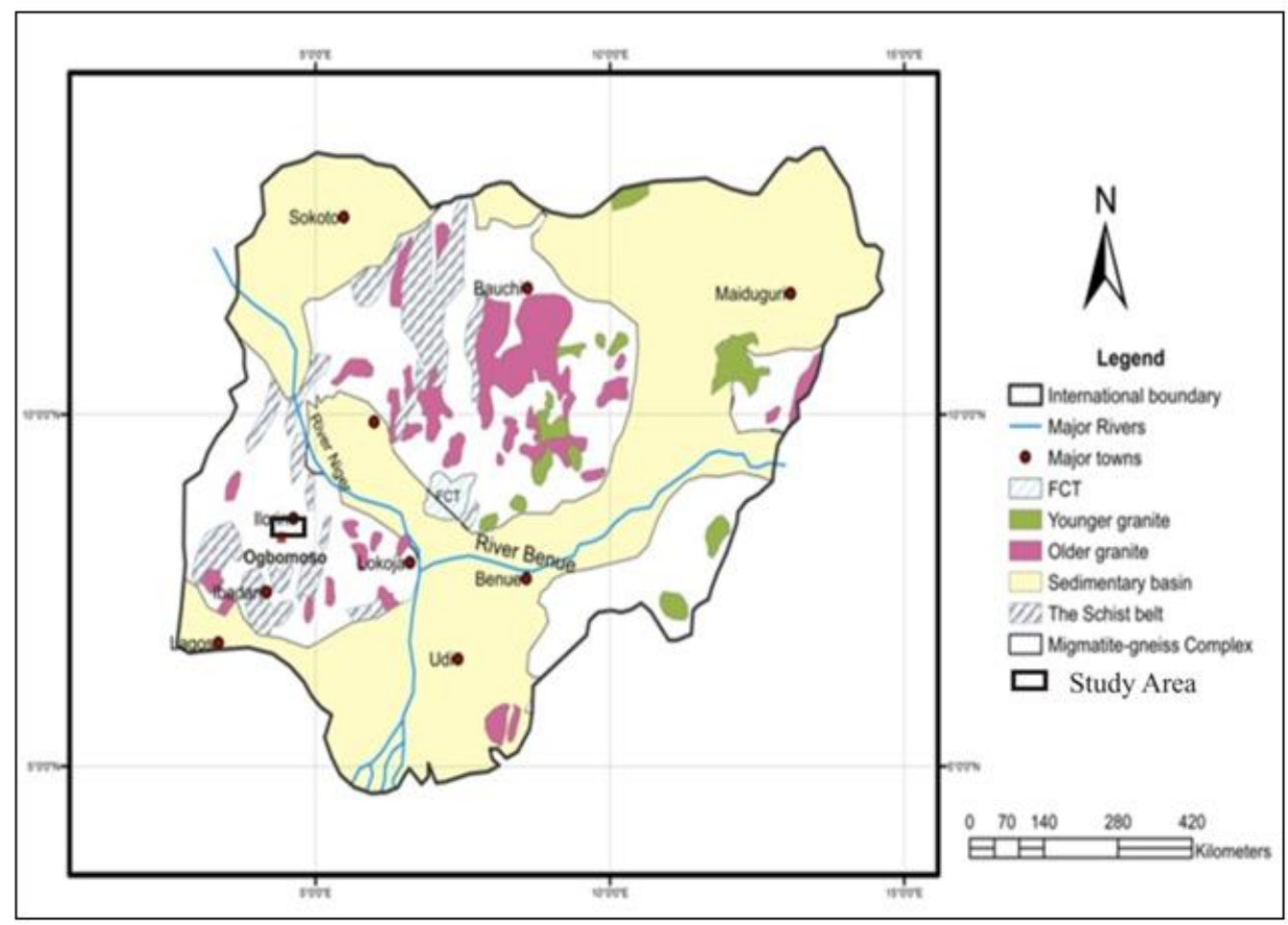

Fig-1: Geological Map of Nigeria showing the Study Area (Geological Survey of Nigeria, 2006) 


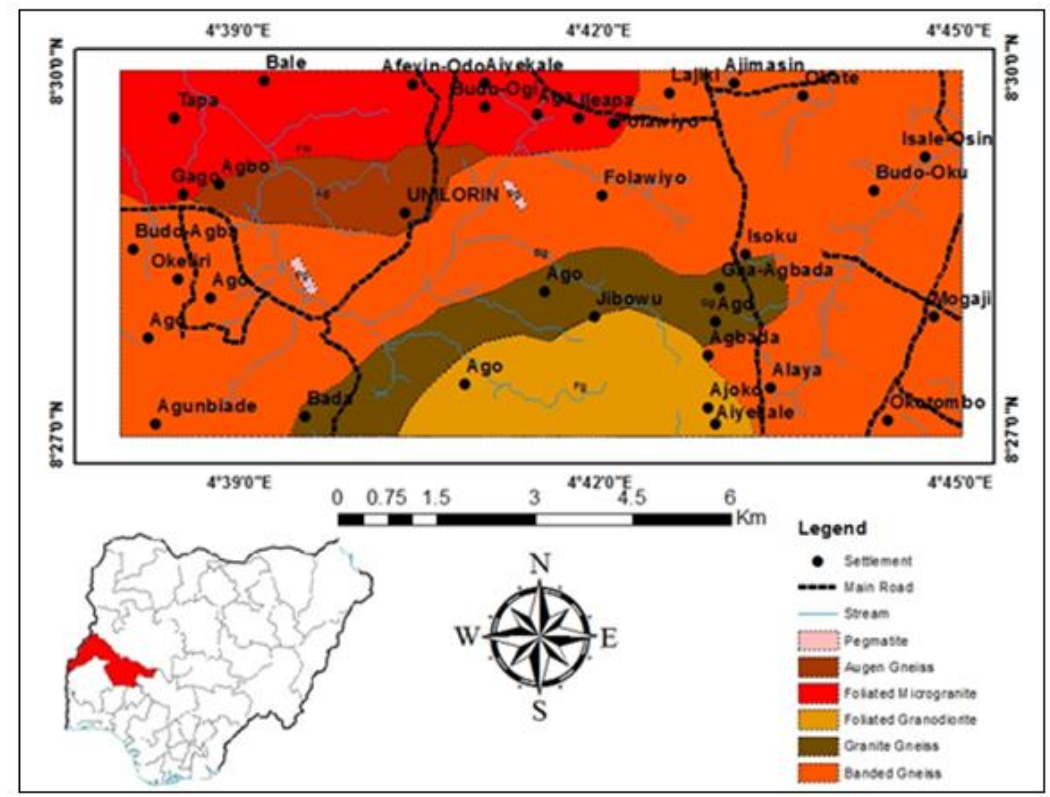

Fig-2: Geological Map of the Study Area

\section{METHODOLOGY}

This study utilized only electrical resistivity method for the assessment of groundwater potential between Unilorin and its environs. A 2-D Electrical Resistivity method was used among the common resistivity methods through Wenner array spreading because of its high signal to noise to strength.
The 2-D Electrical Resistivity Data for this study was acquired using Gridded Wenner Configuration of the Electrical Resistivity method with $\mathrm{AB} / 2$ ranging from $30 \mathrm{~m}$ to $150 \mathrm{~m}$ per layout along the Electrical Resistivity profile at NNW-SSE direction across the prominent zones of structural trending seen on the field which are in NE-SW direction within the study area. This ground truthing was carried out along seven (7) profiles with lengths of $300 \mathrm{~m}$ and $600 \mathrm{~m}$ that contain two and four layouts respectively (Fig-3).

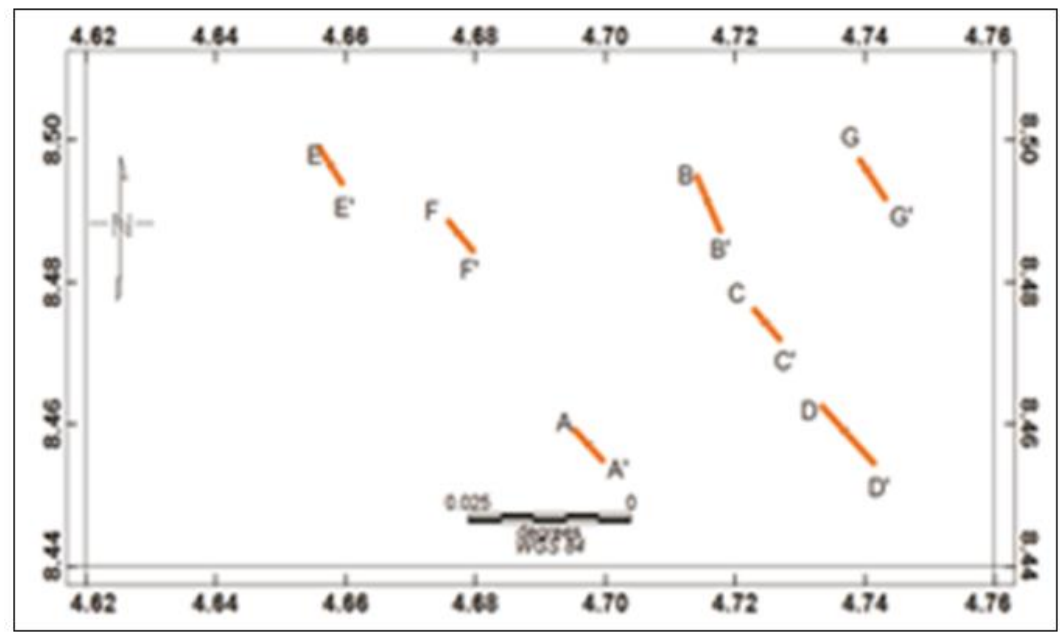

Fig-3: Showing the 7 Profiles within the Study Area

This makes a total of twenty-two layouts with which each layout has $150 \mathrm{~m}$ length. Four profiles among the seven, namely profiles A-A', B-B', C-C' and D-D' had $600 \mathrm{~m}$ length each that contained four layouts while the remaining three profiles, profile E-E', F-F' and G-G' had $300 \mathrm{~m}$ length each with two layouts. A successive regular spacing interval (n) of $10 \mathrm{~m}$ was adopted all through for profiles probing and electrode separations (a) of 10, 20, 30, 40 and $50 \mathrm{~m}$ were employed for sounds probing (Fig-4) as the depth of investigation depends on the electrode separation and geometry with greater electrode separations yielding bulk resistivity measurement from greater depths. Sixteen (16) electrodes were used that give a length of $150 \mathrm{~m}$ for each layout with the maximum depth of penetration to be $28.5 \mathrm{~m}$ (Figure-4). 


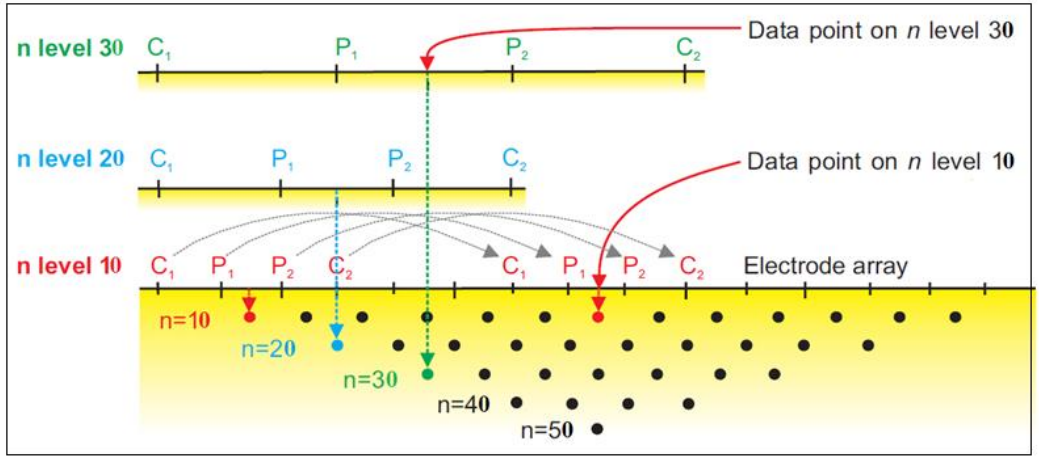

Fig-4: Depths Probe Layout in Gridded Wenner (Alpha) Array [14]

The median depth of investigation for Wenner (Alpha) array is approximately 0.519 times the "a" spacing or one-sixth the array length " $L$ " used [14]. The 2-D EarthImager computer software was employed for carrying out the iteration and inversion processes.

\section{RESULTS AND DISCUSSION}

The resistivity tomograms show the images of the pseudo-sections obtained from the processed data. Figures 5-11, are the electrical tomography results across the prominent zones of geological structural trending seen on the field which are in NE-SW direction within the study area.

The 2-D Electrical Resistivity method revealed the hydrogeological significance of the study since the observed resistivity values are dependent on rock conditions (pore geometry, porosity), the degree of saturation, and the chemistry of the saturating fluid. Detail interpretation of the 2-D Electrical Resistivity Tomograms (ERT) revealed three geo-electric layers namely; the topsoil layer, weathered/fractured rock layer, and the fresh basement rock layer. The topsoil composes of wet unconsolidated sediment and or dry lateritic sand with resistivity of very low to very high values respectively. The maximum thickness of this layer is about $7.80 \mathrm{~m}$. This layer is underlain by the weathered/fractured rock layer with intermediate resistivity value and it has thicknesses that range from 9.44 to $28.5 \mathrm{~m}$. The last layer is the crystalline basement rock of resistivity values ranging from 2000 to $10000 \Omega \mathrm{m}$ and the depth to the bedrock is greater than $28.5 \mathrm{~m}$ with an infinity thickness. This crystalline basement rock was not penetrated by the electrical survey in most places within the probed locations at its maximum depth of penetration of $28.5 \mathrm{~m}$ except in profile F-F' where the depth is shallower, ranging from 0.2 to $10.44 \mathrm{~m}$ at the NNW portion of profile F-F'. The weathered/fractured rock layer is characterized by low electrical resistivity values and within this thick weathered/fractured basement rock layer, there are several very low resistivity structures $(<30 \Omega \mathrm{m})$ oriented approximately in North-South direction. This layer corresponds to the groundwater aquifer in the area with the thickness greater than $22.0 \mathrm{~m}$ across the profiles except at NNW portion along profile F-F' where the thickness is less than $9.44 \mathrm{~m}$. This layer corresponds to the possible basement aquifer that may yield sufficient groundwater to wells in the Nigerian Basement Complex region. All the probed structures across the study area were proven to be proficient in groundwater.

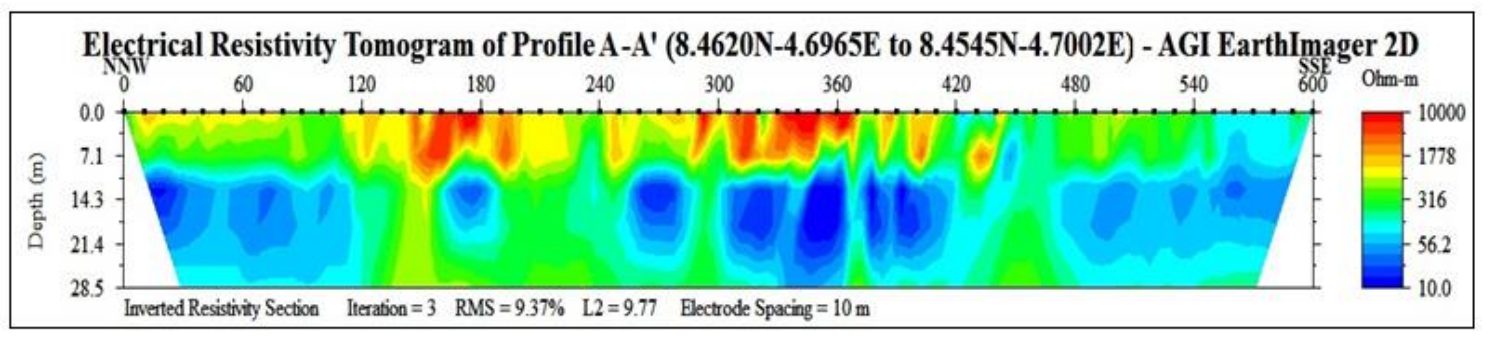

Fig-5: Inverted Resistivity Model (Tomogram) of Profile A-A'

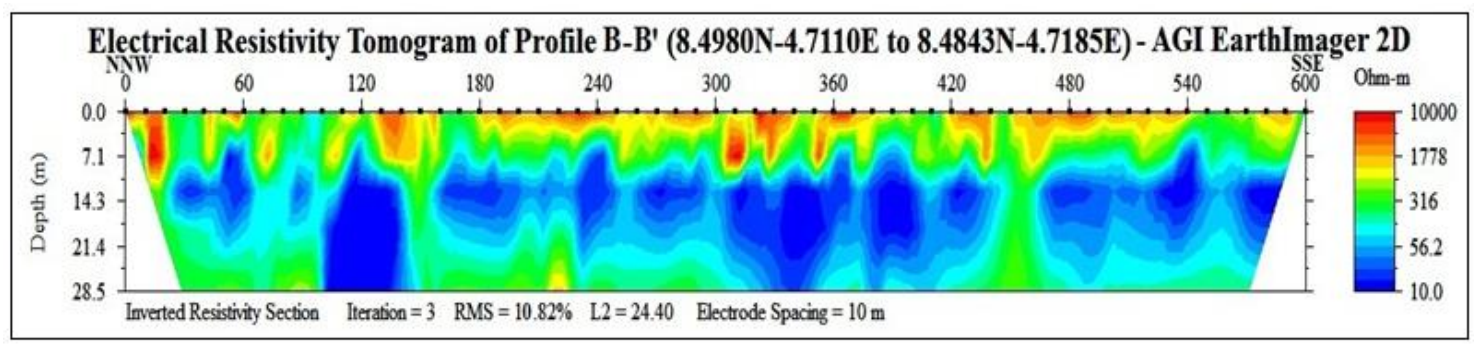

Fig-6: Inverted Resistivity Model (Tomogram) of Profile B-B' 


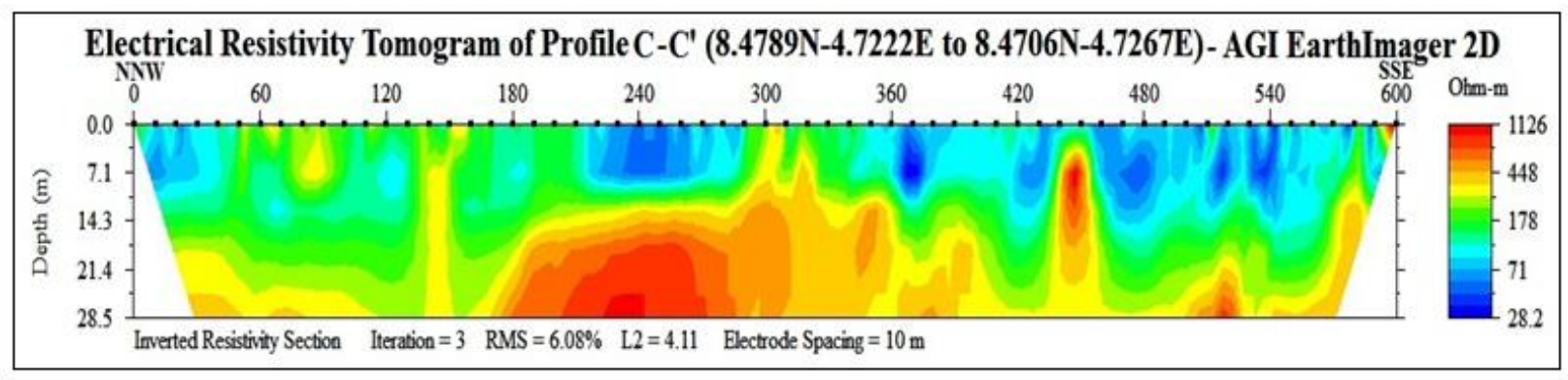

Fig-7: Inverted Resistivity Model (Tomogram) of Profile C-C'

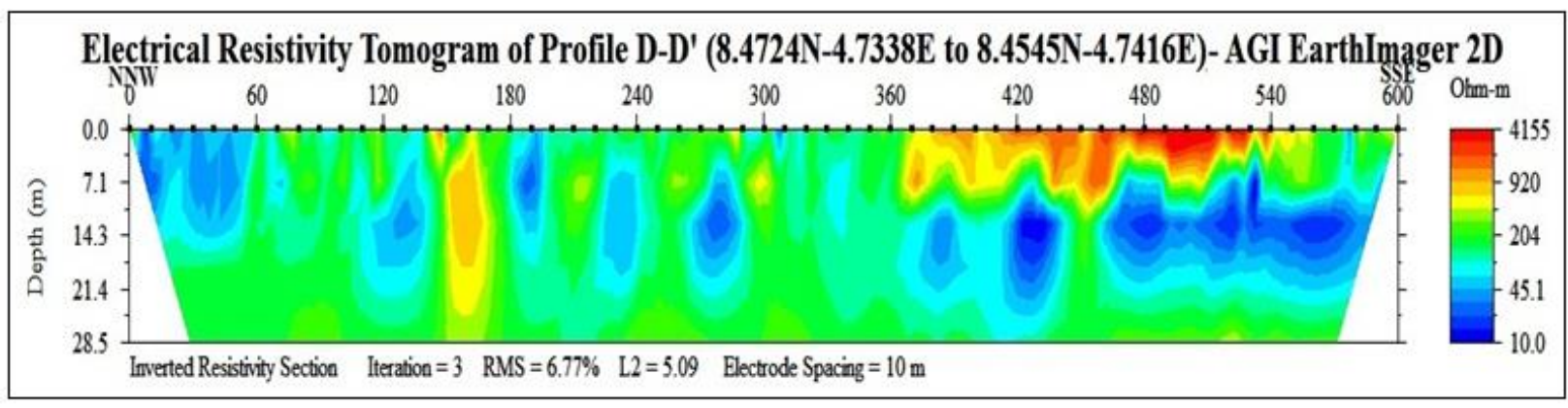

Fig-8: Inverted Resistivity Model (Tomogram) of Profile D-D'

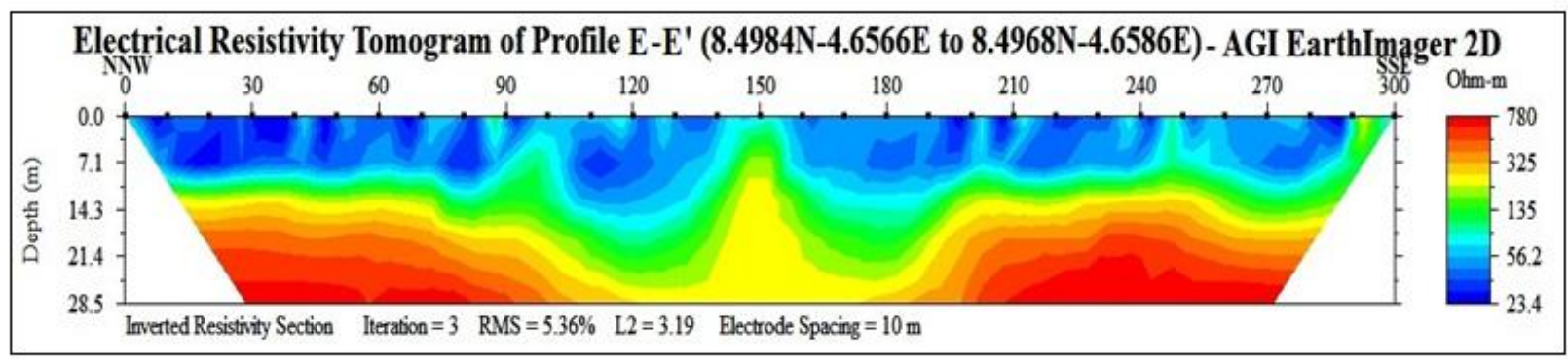

Fig-9: Inverted Resistivity Model (Tomogram) of Profile E-E'

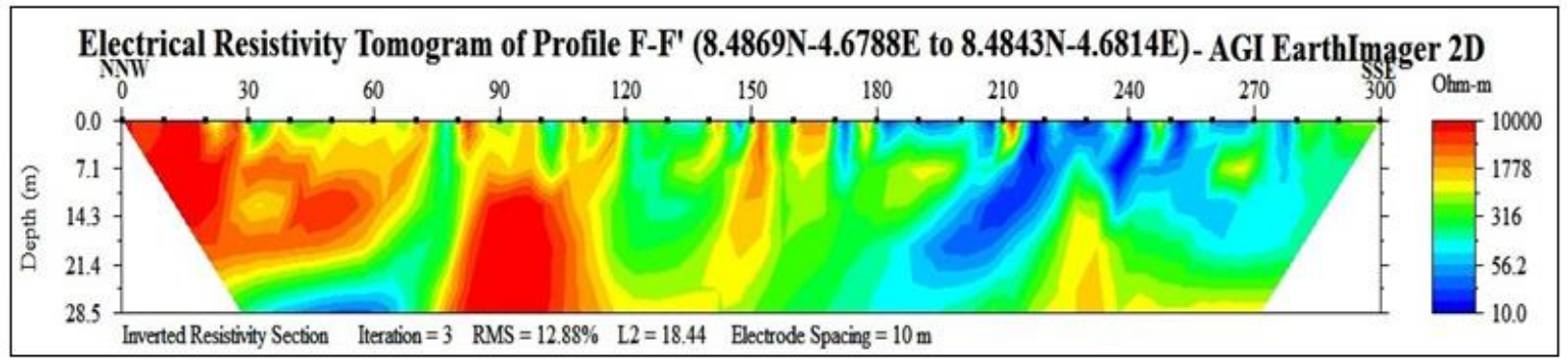

Fig-10: Inverted Resistivity Model (Tomogram) of Profile F-F'

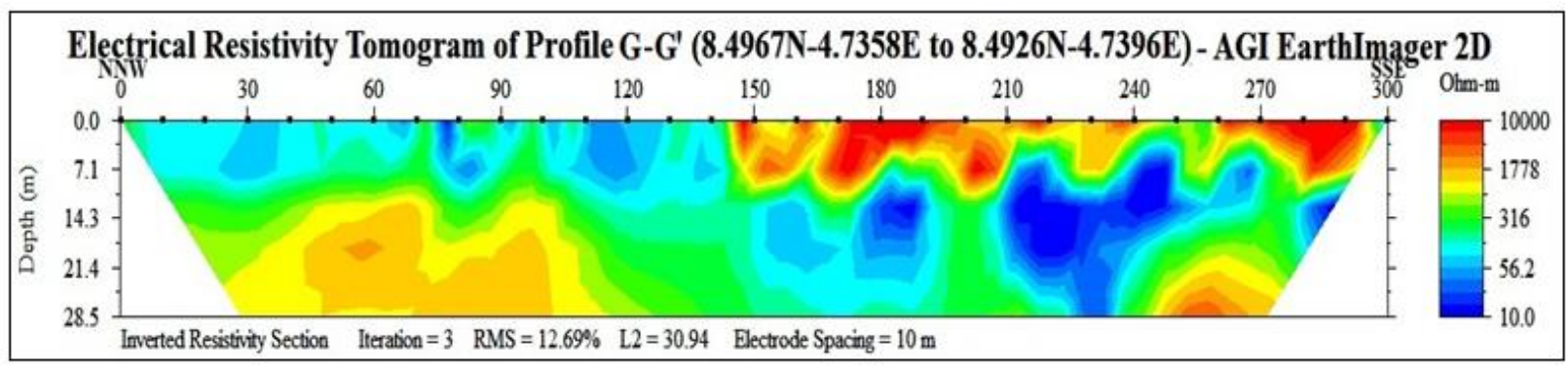

Fig-11: Inverted Resistivity Model (Tomogram) of Profile G-G' 


\section{CONCLUSION}

In conclusion, 2-D Electrical Resistivity Tomograms affirmed that the areas of low resistivity values are aquiferous with pronounced thickness favourable for an economical groundwater supply for the study area and its environs. The results have located potential places of deep weathered zones that are laterally extensive of thickness generally greater than $22.0 \mathrm{~m}$ and with a low resistivity values with less than $30 \Omega \mathrm{m}$ at some zones, depicting some level of confidence in the groundwater potential of the study area. This study confirms some levels of integrity in the 2-D Electrical Resistivity Tomographic technique for groundwater exploration.

In the future, if possible more profile should be done so as to cover the areas where the study profiles do not covered for more detailed understanding of the study area.

\section{REFERENCES}

1. Ajayi, O., \& Adegoke-Anthony, C. W. (1988). Groundwater prospects in the basement complex rocks of Southwestern Nigeria. Journal of African Earth Sciences (and the Middle East), 7(1), 227235.

2. Al-Garni, M. A. (2009). Geophysical investigations for groundwater in a complex subsurface terrain, Wadi Fatima, KSA. Jordan journal of Civil Engineering, 3(2), 118-136.

3. Barker, R. D. (2001). Imaging fractures in hardrock terrain. University of Birmingham, $U K$. http://www.bham.ac.uk/EarthSciences/research/hy dro/envgeo/.

4. Sharma, S. P., \& Baranwal, V. C. (2005). Delineation of groundwater-bearing fracture zone in a hard rock area integrating Very Low Frequency electromagnetic and resistivity data, Journal of Applied Geophysics. 57, 155-166.

5. Jayeoba, A., \& Oladunjoye, M. A. (2015). 2-D Electrical Resistivity Tomography for Groundwater Exploration in Hard Rock Terrain.
International journal of Science and Research, 4(4), 154-156.

6. Olorunfemi, M. O., \& Fasuyi, S. A. (1993). Aquifer Types and the Geoelectric/Hydrogeologic Characteristics of Part of the Central Basement Terrain of Nigeria (Niger State). Journal of African Earth Sciences, 16, 309-317.

7. Yang, C. M., Chang, P. H., You, J. I., \& Tsai, L. L. (2002). Significant resistivity changes in the fault zone associated with the 1999 Chi-Chi earthquake, west central Taiwan, Tectonophysics, 350, 299-313.

8. Hauck, C., Muhil, D. V. and Maurer, H. (2003). Using DC resistivity tomography to detect and characterize mountain permafrost, Geophysical Prospecting. 51, pp. 273-284.

9. Crook, N., Binley, A., Knight, R., Robinson, D. A., Zarnetske, J., \& Haggerty, R. (2008). Electrical resistivity imaging of the architecture of substream sediments. Water Resources Research, 44(4).

10. Zhou, Q. Y., Matsui, H., \& Shimada, J. (2004). Characterization of the unsaturated zone around a cavity in fractured rocks using electrical resistivity tomography. Journal of Hydraulic Research, 42(S1), 25-31.

11. Rao, B. V., Prasad, Y. S., \& Reddy, K. S. (2013). Hydrogeophysical investigations in a typical Khondalitic terrain to delineate the kaolinised layer using resistivity imaging. Journal of the Geological Society of India, 81(4), 521-530.

12. Loko, M. H. (2000). Electrical Imaging Surveys for Environmental and Engineering Studies, a practical guide to 2-D and 3-D surveys, 6 .

13. Oluyide P. O., Nwajide C. S., \& Oni, A. O. (1998). The Geology of Ilorin Area with Explanations on the 1:250,000 Series, Sheet 50 (Ilorin). Geological Survey of Nigeria Bulletin, 42, 1-84.

14. Loke, M. H. (2015). Tutorial. 2-D and 3-D Electrical Imaging Surveys. 2015 Revised Edition, www.geometrics.com., Geotomo Software Pty. 